\title{
The mechanisms of substrates interaction with the active site of Mycobacterium tuberculosis tyrosyl-tRNA synthetase studied by molecular dynamics simulations
}

\author{
V. V. Mykuliak ${ }^{1,2}$, A. I. Kornelyuk ${ }^{1,2}$ \\ ${ }^{1}$ Institute of High Technologies, Taras Shevchenko National University of Kyiv \\ 64, Volodymyrska Str., Kyiv, Ukraine, 01601 \\ ${ }^{2}$ Institute of Molecular Biology and Genetics, NAS of Ukraine \\ 150, Akademika Zabolotnoho Str., Kyiv, Ukraine 03680 \\ v.mykuliak@imbg.org.ua
}

\begin{abstract}
Aim. To study the mechanisms of substrates interaction with the active site of Mycobacterium tuberculosis tyrosyl-tRNA synthetase (MtTyrRS). Methods. Complexes of MtTyrRS with tyrosine, ATP and tyrosyl adenylate were constructed by superposition of the MtTyrRS structure and crystallographic structures of bacterial TyrRS. All complexes of MtTyrRS with substrates were investigated by molecular dynamics (MD) simulations in solution. Results. It was shown the formation of network of hydrogen bonds between substrates and the MtTyrRS active center, which were stable in the course of MD simulations. ATP binds in the active site both by hydrogen bonds and via electrostatic interactions with Lys231 and Lys234 of catalytic KFGKS motif. Conclusions. The L-tyrosine binding site in the enzyme active site is negatively charged, whereas the ATP binding site contains positive Lys231 and Lys234 residues of catalytic KFGKS motif. The occupancy of H-bonds between substrates and the enzyme evidences a significant conformational mobility of the active site.
\end{abstract}

Keywords: tyrosyl-tRNA synthetase, Mycobacterium tuberculosis, substrate, hydrogen bond, molecular dynamics, grid.

Introduction. Tyrosyl-tRNA synthetase from $M$. tuberculosis (MtTyrRS) belongs to a class I of aminoacyltRNA synthetases (aaRSes) that catalyze the attachment of tyrosine to its cognate tRNA ${ }^{\text {Tyr }}$ at the preribosomal protein synthesis step.

The catalytic domain of MtTyrRS has the Rossmann fold and the active center has the HIGH and KMSKS (KFGKS in MtTyrRS) motifs that catalyze the amino acid activation with ATP [1-3]. MtTyrRS is a promising antibiotic target for discovering and developing new selective inhibitors [4-7]. In general, the aminoacylation reaction has two steps: L-tyrosine is activated by ATP, forming the enzyme-bound tyrosyladenylate intermediate, and at the second step of the re-

(C) Institute of Molecular Biology and Genetics, NAS of Ukraine, 2014 action, the activated tyrosine transfers to tRNA ${ }^{\text {Tyr }}$ to form the tyrosyl-tRNA ${ }^{\text {Tyr }}$ complex [1-3].

The inhibitor SB-219383 and its analogues are a class of specific inhibitors of bacterial TyrRS, but their polarity prevents the transport across the bacterial cell wall. SB-219383 shows the competitive inhibitory activity against Staphylococcus aureus TyrRS $\left(K_{i}=\mathrm{IC}_{50}=\right.$ $=0.6 \mathrm{nM}$ for $S$. aureus TyrRS; $\mathrm{IC}_{50}=22 \mu \mathrm{M}$ for mammalian TyrRS) and a weak anti-bacterial activity against some Streptococcal strains in vitro (MIC $=32 \mu \mathrm{g} / \mathrm{ml}$ ) $[8,9]$. Other pyranosyl and carbocyclic analogues of SB-219383 have been synthesized to reduce its overall polarity and thus improve its penetration through the bacterial cell wall, although only one compound exhibits a weak antimicrobial activity against Streptococcus pyogenes (MIC $8 \mathrm{mg} / \mathrm{ml}$ ) [10]. 
The active sites of bacterial aaRSes have being studied for years. The 3D structures of TyrRS from E. coli (1VBM, 1VBN, 1WQ3, 1WQ4, 1X8X) [11, 12], Thermus thermophilus (1H3E, 1H3F) [13], S. aureus (1JII, 1JIJ, 1JIK, 1JIL) [14], Bacillus stearothermophilus (1TYD, 2TS1, 3TS1, 4TS1) [15], and M. tuberculosis (2JAN) [16] were solved by X-ray crystallography. Tyr RS [17-20, 26], MetRS [21], AspRS [22, 23], LysRS [24] and TrpRS [25] were studied by the MD simulations. The structure of full-length Bos taurus TyrRS was modeled and analyzed [26]. Mammalian TyrRS was studied by fluorescence spectroscopy [27].

Since the different bacterial TyrRSes have homologous catalytic domains, their active sites are similar [4]. According to the data of the Protein database of NCBI, the $M t$ TyrRS active center (H37Rv strain) is formed by following 20 residues: Tyr36, Gly38, Phe39, Asp40, His47, Gly49, His50, Tyr171, Gln175, Asp178, Gln191, Gly193, Gly194, Gln197, Leu223, Val224, Lys231, Phe232, Gly233, Lys234.

In this paper, we have investigated the mechanisms of the substrates interaction with the MtTyrRS active site. Specifically, we have studied MtTyrRS in the complexes with L-tyrosine, ATP and tyrosyl-adenylate by $100 \mathrm{~ns}$ MD simulations. The data on dynamic binding of the substrates in the active center are important to design new inhibitors. The search for and development of inhibitors based on dynamic pharmacophores may help to find a new specific inhibitor of MtTyrRS, non-toxic to humans.

Materials and methods. Initial structures. Structure of the MtTyrRS dimer in free state was prepared according to the scheme described in our previous work [28]. The crystallographic structures of complexes of bacterial TyrRSes were used to build the MtTyRS structure in the complexes with substrates. To construct the complexes we superimposed the atomic coordinates of the protein - 2JAN [16] and ligand (Tyr) - 1X8X (E.coli TyrRS) [11], keeping the protein structure and Tyr invariable. The same strategy was applied to generate the complex of MtTyrRS with ATP $(1 \mathrm{H} 3 \mathrm{E}-T$. thermophilus TyrRS) [13], and with the tyrosyl-adenylate intermediate (1VBM - E. coli TyrRS) [11]. In the latter case we replaced the atom $\mathrm{S}$ by $\mathrm{P}$, to obtain the tyrosyladenylate but not its analogue.
Molecular dynamics. MD simulations were performed using the GROMACS 4.5 package [29]. Each system was simulated for 100 ns with the Amber ff99SB-ILDN force field [30] and three times with the CHARMM27 force field [31]. The ligand topologies for the Amber ff99SB-ILDN force field were prepared by using the acpype (AnteChamber PYthon Parser interfacE) scripts [32], based on the antechamber suite. The ligand topologies for the CHARMM27 force field were prepared by using the SwissParam web-service [33]. The protein was placed in a triclinic water box with the minimum distance between $M t$ TyrRS and the box wall of $1 \mathrm{~nm}$. The explicit TIP3P water molecules were used. All simulations were performed under periodic boundary conditions. $\mathrm{Na}^{+}$and $\mathrm{Cl}^{-}$counterions were added to neutralize completely the system at $150 \mathrm{mM}$ $\mathrm{NaCl}$ salt concentration. Each system was energy-minimized and then equilibrated with positioning restraints on heavy atoms of the protein before the simulations were initiated. The leap-frog integration algorithm was used, with a 2 fs timestep. All bond lengths were constrained using the LINCS algorithm. Unless otherwise stated, the long-range electrostatic interactions were computed using the fourth-order particle mesh Ewald (PME) method with a Fourier spacing of $0.16 \mathrm{~nm}$. The real space coulombic interactions and the pair-list calculations were set to $1.0 \mathrm{~nm}$. A twin-range cutoff of $1 \mathrm{~nm}$ was used for the Van der Waals interactions. The temperature and pressure were maintained by coupling the temperature and pressure baths using the $V$-rescale and Parrinello-Rahman methods with relaxation times of 0.1 and $0.5 \mathrm{ps}$, respectively. A temperature of $310 \mathrm{~K}$ and pressure of $1 \mathrm{~atm}$ were used. All MD simulations were performed using the services of the MolDynGrid virtual laboratory (http://moldyngrid.org), at the ICYB and ISMA clusters of the Ukrainian National Grid environment [34-36].

Graphical and structural analysis. The PyMOL program was used for the visualization and graphical structure analysis [37]. The Root Mean Square Deviations (RMSD) and Root Mean Square Fluctuations (RMSF) were calculated using the $g_{-} r m s$ and $g_{-} r m s f$ programs of GROMACS, respectively. Hydrogen bonds were calculated with $g \_$hbond program. The LigPlot+ program was used for schematic visualization of the hydro- 

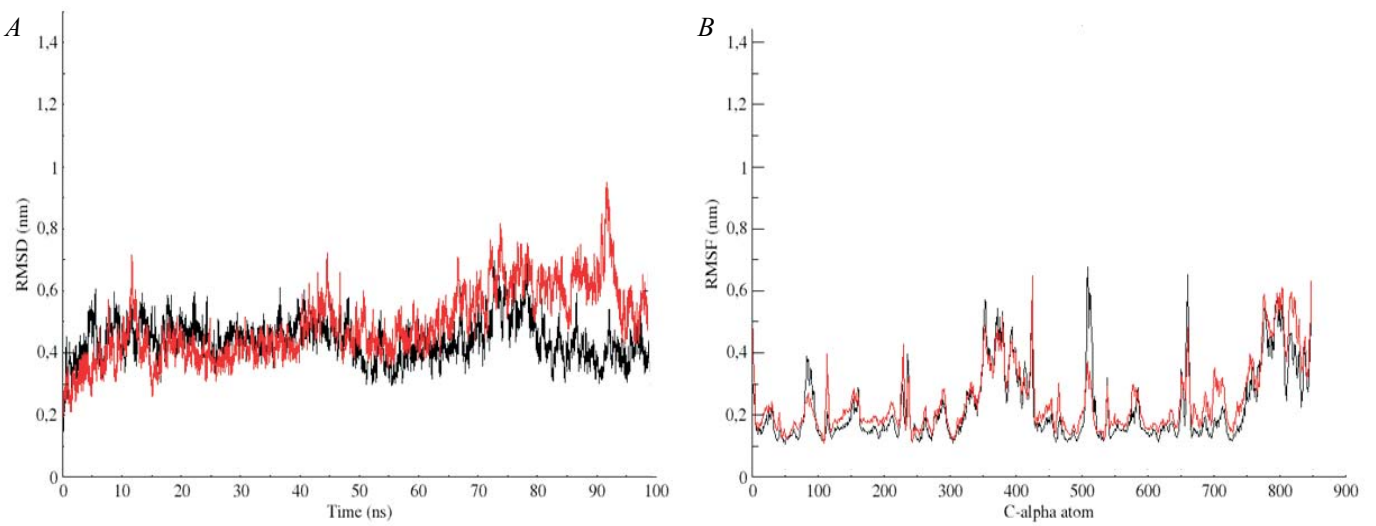

Fig. 1. RMSD $(A)$ and RMSF $(B)$ of $\mathrm{C}_{\alpha}$ atoms from the initial structure of MtTyrRS in the complex with tyrosyladenylate intermediate during $100 \mathrm{~ns}$ MD simulations

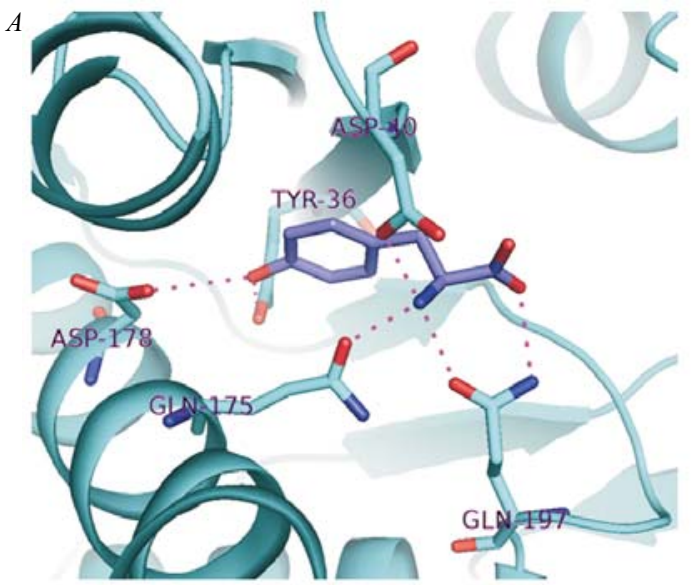

$B$

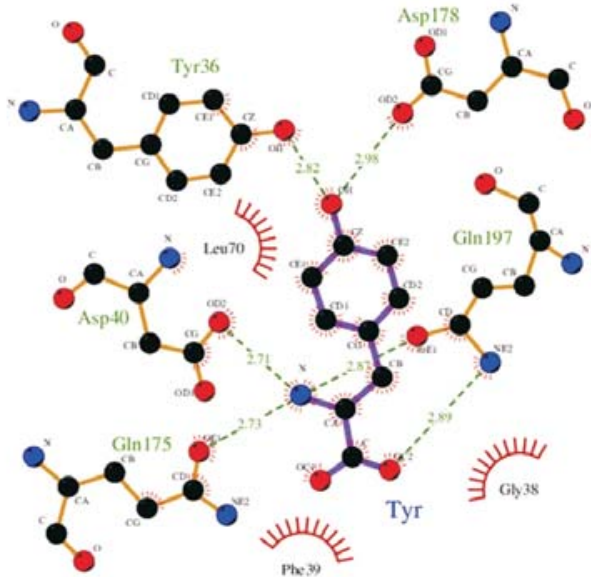

Fig. 2. Hydrogen bonds between the tyrosine and residues of the MtTyrRS active center $(A)$ and schematic representation of $\mathrm{H}$-bonds between the tyrosine and residues of the active center $(B)$

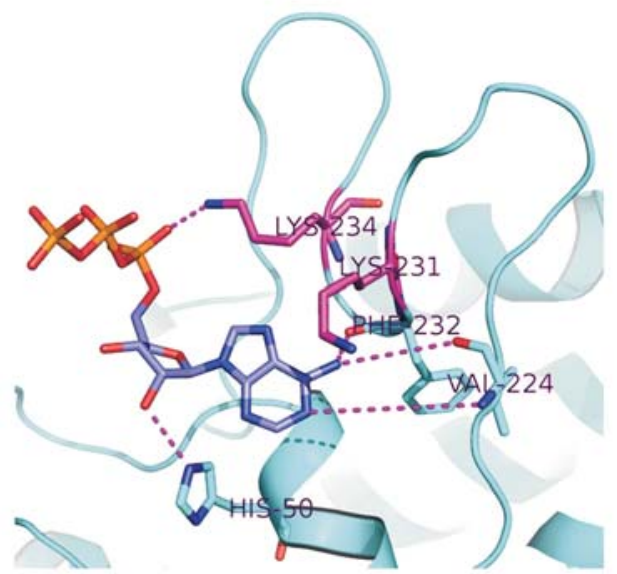

$B$

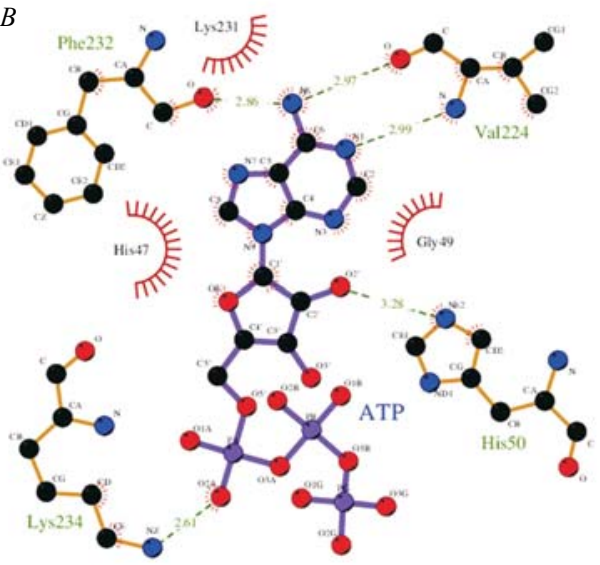

Fig. 3. ATP and residues of the active center that form H-bonds. Lys231 and Lys 234 (magenta) of the catalytic KFGKS motif $(A)$ and schematic representation of H-bonds between the ATP and residues of the active center $(B)$ gen bonds between the substrate and the residues of the active center [38].

Results and discussion. To check the global structural stability in the course of MD simulations the RMSD and RMSF of C-alpha atoms of MtTyrRS in complex with tyrosyl-adenylate were monitored (Fig. 1). RMSD increase up to $\sim 10 \mathrm{~ns}$, and then become more stable $(\sim 3-$ 7 C). After $\sim 70$ ns of simulations RMSD increase again up to $\sim 9.3 \mathrm{C}$. This is due to high mobility of the C-termi- nal domains [20]. RMSF show that besides the C-modules, the catalytic KMSKS loops are also highly mobile elements of the protein [28].

In order to evaluate the substrate binding in the MtTyrRS active center the H-bonds were calculated with their occupancy over the entire $100 \mathrm{~ns}$ of MD simulations (Table). L-tyrosine in the active site forms $\mathrm{H}$ bonds to Tyr36, Asp40, Gln175, Asp178 and two Hbonds with Gln197 (Fig. 2). Occupancy of these H- 


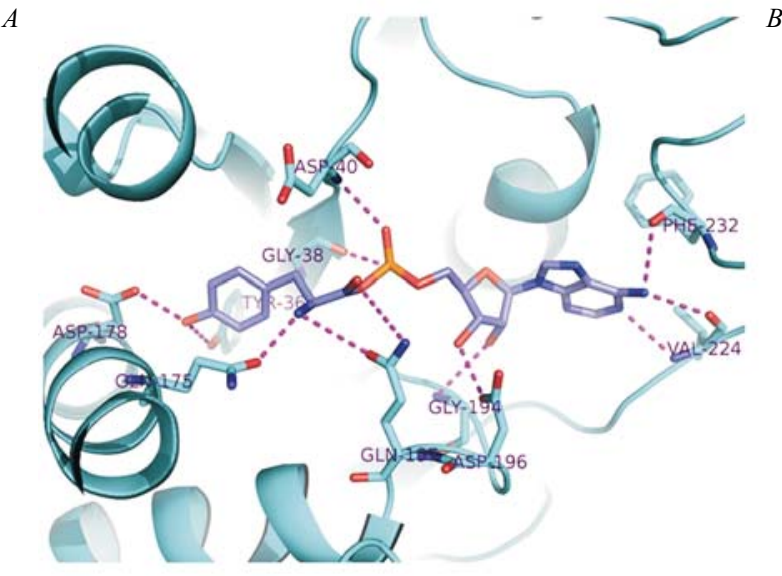

bonds is about 30-40\% of $100 \mathrm{~ns}$ of MD simulations for residues of loops, and up to $99 \%$ of $100 \mathrm{~ns}$ of MD simulations for residues of $\alpha$-helixes and $\beta$-strand of the enzyme active center. It is worth to note, that the L-tyrosine binding pocket is negatively charged because of Asp40 and Asp178.

For the binding of ATP in the active center, Lys 231, Phe232 and Lys234 of the catalytic KFGKS sequence are important. The positively charged Lys 231 and Lys 234 interact with the negative phosphate groups of ATP. Phe232 and Lys234 have H-bonds with ATP. Besides, one H-bond with ATP is formed by His50, and two bonds - by Val224 (Fig. 3). Due to the high mobility of the catalytic loop, the occupancy of each H-bond to ATP is not more than 50\% of 100 ns of MD simulations (Table). The catalytic loop catalyzes the formation of the tyrosyl-adenylate intermediate by interacting with the phyrophosphate moiety of ATP [39].

The tyrosyl-adenylate intermediate occupies entire pocket of the active site interacting with the catalytic

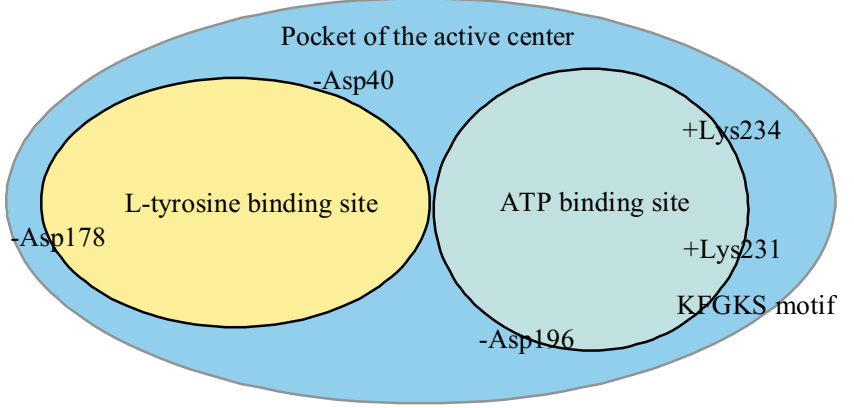

Fig. 5. Schematic representation of the MtTyrRS active center. The Ltyrosine binding site has negatively charged Asp40 and Asp178. The ATP binding site has negatively charged Asp196 and positively charged Lys231 and Lys234 of the catalytic sequence

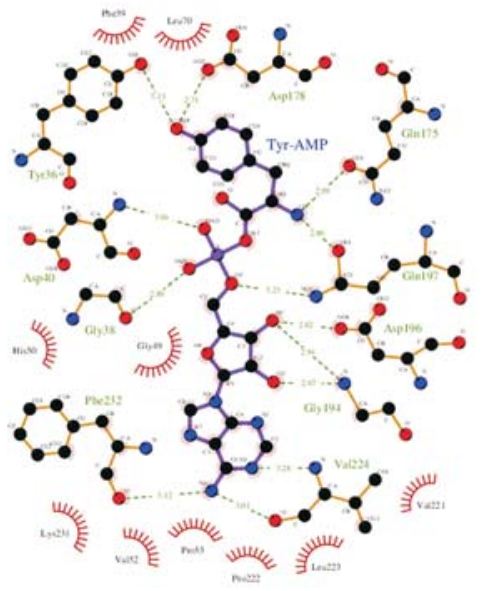

Fig. 4. Hydrogen bonds between the tyrosyl-adenylate and residues of the MtTyrRS active center $(A)$ and schematic representation of $\mathrm{H}$-bonds between the tyrosyl-adenylate and residues of the active center $(B)$
Hydrogen bonds between substrates and the MtTyrRS active center

\begin{tabular}{c|c|c}
\hline Hydrogen bonds & Distance, C & Occupancy, \\
\hline Mt TyrRS-Tyr & & \\
Tyr36-OH-OH & 2.82 & 75.41 \\
Asp40-OD2-H1N & 2.71 & 30.42 \\
Gln175-OE1-H2N & 2.73 & 47.56 \\
Asp178-OD2-HO & 2.98 & 99.21 \\
Gln197-NE2H-OC2 & 2.89 & 37.74 \\
Gln197-OE1-H3N & 2.87 & 39.56
\end{tabular}

MtTyrRS-ATP

$\begin{array}{lll}\text { His50-NE2H-O2' } & 3.28 & 20.00 \\ \text { Val224-O-H20N6 } & 2.81 & 47.47 \\ \text { Val224-NH-N1 } & 3.03 & 49.71 \\ \text { Phe232-O-H1N6 } & 2.86 & 18.70 \\ \text { Lys234-NZHZ2-O2A } & 2.61 & 43.68\end{array}$

MtTyrRS-Tyr-AMP

Tyr36-OH-OH

3.11

33.44

Gly38-O-H24OAE

2.89

20.01

Asp40-NH-OAD

3.04

88.37

Gln175-OE1-H1N

2.69

89.49

Asp178-OD2-HO

2.71

99.07

Gly194-NH-O2'

2.67

26.89

Asp196-OD1-HO3'

2.62

52.80

Gln197-NE2H-O5'

3.23

21.87

Gln197-OE1-H2N

2.86

37.08

Val224-O-H1N6

3.01

60.70

Val224-NH-N1

3.28

66.12

Phe232-O-H2N6

3.12

52.38

$\mathrm{N}$ o t e. For each hydrogen bond the percentage occupancy was calculated. 
loop (Fig. 4). The substrate forms H-bonds with residues that interact with other substrates (tyrosine and ATP) and with Tyr38, Gly194 and Asp196 (Table). Hbonds occupancy reveals stability of the tyrosyl-adenylate in the enzyme active center. In general, the $M t$ TyrRS active center can be divided into two parts: the L-tyrosine binding site and the ATP binding site (Fig. 5). The L-tyrosine binding site involves the negatively charged Asp40 and Asp178. The ATP binding site contains the negative Asp196 as well as the positive Lys 231 and Lys234 of the universal catalytic KMSKS motif of the aaRS of class I. In bacterial TyrRS, the Lys 231 and Lys234 of the catalytic KMSKS sequence stabilize the intermediate state for the tyrosine activation by interaction with the phyrophosphate moiety of ATP substrate [39].

Conclusions. In this study, we have investigated the mechanisms of the substrates interaction with the active center of MtTyrRS in solution. We have performed 100 ns MD simulations of the MtTyrRS dimer in complexes with L-tyrosine, ATP and tyrosyl-adenylate intermediate. The L-tyrosine binding site is negatively charged, whereas the ATP binding site has the positively charged Lys231 and Lys234 of the catalytic sequence. The Hbonds occupancy reveals significant conformational mobility of the active center of $M t$ TyrRS in solution.

Механізм взаємодії субстратів 3 активним центром тирозилтРНК синтетази Mycobacterium tuberculosis за даними молекулярної динаміки

В. В. Микуляк, О. І. Корнелюк

Резюме

Мета. Дослідити механізми взаємодї субстратів реакиії аміноацилювання з активним изентром тирозил-тРНК синтетази еубактерї Mycobacterium tuberculosis (MtTyrRS). Memoдu. Cynepnoзицією MtTyrRS з кристалографічними структурами бактерійних TyrRS побудовано комплекси з тирозином, тирозином, АTФ $i$ тирозиладенілатом. Комплекси MtTyrRS з субстратами вивчали методом моделювання молекулярної динаміки (МД) у розчині. Peзультати. Показано водневі зв 'язки між субстратами і активним центром MtTyrRS та їхню стабільність у процесі МД. Стабільність АТФ в активному центрі забезпечується водневими зв'язками, а також електростатичними взаємодіями з Lys231 ma Lys 234 каталітичного мотиву KFGKS. Висновки. Ділянка зв'язування L-тирозину в активному центрі ферменту є негативно зарядженою, тоді як ділянка зв 'язування АТФ має позитивно заряджені Lys231 і Lys234 каталітичної послідовності KFGKS. Процентне співвідношення тривалості існування водневих зв'язків, які формуються між субстратами та ферментом, до загального часу моделювання МД свідчить про конформаційну рухливість активного иентра.

Ключові слова: тирозил-тРНК синтетаза, Мусоbacterium tuberculosis, субстрат, водневий зв 'язок, молекулярна динаміка, грид.

Механизм взаимодействия субстратов с активным центром тирозил-тРНК синтетазы Mycobacterium tuberculosis по данным молекулярной динамики

В. В. Микуляк, А. И. Корнелюк

Резюме

Цель. Исследовать механизмы взаимодействия субстратов реакции аминоацилирования с активным центром тирозил-тРНК синтетазы эубактерии Mycobacterium tuberculosis (MtTyrRS). Meтоды. Суперпозиичиеи MtTyrRS с кристаллографическими структурами бактериальных TyrRS построены комплексы с тирозином, тирозином и АТФ и тирозиладенилатом. Комплексы MtTyrRS с субстратами изучали методом симуляции молекулярной динамики (МД) в растворе. Результаты. Показаны водородные связи между субстратами и активньмм цееттром MtTyrRS и их стабильность в проиессе МД. Стабильность АТФ в активном иентре обеспечивается водородными связями, а также электростатическими взаимодействиями с Lys231 и Lys234 каталитического мотива KFGKS. Выводы. Сайт связывания L-тирозина в активном центре фермента заряжен отрицательно, в то время как участок связывания АТФ имеет положительные Lys231 и Lys234 каталитической последовательности KFGKS. Процентное соотношение длительности существования водородных связей, формируюшихся между субстратами и ферментом, кобщему времени моделирования МД свидетельствует о конформационной подвижности активного иенттра.

Ключевые слова: тирозил-тРНК синтетаза, Мусоbаcterium tuberculosis, субстрат, водородная связь, молекулярная динами$к а$, грид.

\section{REFERENCES}

1. Kornelyuk A. Structural and functional investigation of mammalian tyrosyl-tRNA synthetase. Biopolym Cell. 1998; 14(4):349-59.

2. Bonnefond L, Giege R, Rudinger-Thirion J. Evolution of the tRNA(Tyr)/TyrRS aminoacylation systems. Biochimie. 2005; 87(9-10):873-83.

3. Bedouelle H. Recognition of tRNA(Tyr) by tyrosyl-tRNA synthetase. Biochimie. 1990; 72(8):589-98.

4. Odynets' $K O$, Korneliuk OI. A model of three-dimensional structure of Mycobacterium tuberculosis tyrosyl-tRNA synthetase. Ukr Biokhim Zh. 2008; 80(5):62-75.

5. Hoffmann $M$, Torchala $M$. Search for inhibitors of aminoacyltRNA synthases by virtual click chemistry. J Mol Model. 2009; 15(6):665-72.

6. Eitner K, Gaweda T, Hoffmann M, Jura M, Rychlewski L, Barciszewski J. eHiTS-to-VMD interface application. The search for tyrosine-tRNA ligase inhibitors. J Chem Inf Model. 2007 ; 47(2):695-702.

7. Manning $J$, Vincent $J$. Tyrosyl tRNA synthetase: A new site for antibiotics. Literature Seminar. Univ. of Alabama, 2006; 10 p.

8. Stefanska AL, Coates NJ, Mensah LM, Pope AJ, Ready SJ, Warr $S R$. SB-219383, a novel tyrosyl tRNA synthetase inhibitor from 
a Micromonospora sp. I. Fermentation, isolation and properties. J Antibiot (Tokyo). 2000; 53(4):345-50.

9. Houge-Frydrych CS, Readshaw SA, Bell DJ. SB-219383, a novel tyrosyl tRNA synthetase inhibitor from a Micromonospora sp. II. Structure determination. J Antibiot (Tokyo). 2000; 53(4): 351-6.

10. Jarvest RL, Berge JM, Brown P, Hamprecht DW, McNair DJ, Mensah L, O'Hanlon PJ, Pope AJ. Potent synthetic inhibitors of tyrosyl tRNA synthetase derived from C-pyranosyl analogues of SB-219383. Bioorg Med Chem Lett. 2001; 11(5):715-8.

11. Kobayashi T, Takimura T, Sekine R, Kelly VP, Kamata K, Sakamoto K, Nishimura S, Yokoyama S. Structural snapshots of the KMSKS loop rearrangement for amino acid activation by bacterial tyrosyl-tRNA synthetase. J Mol Biol. 2005; 346(1):105-17.

12. Kobayashi T, Sakamoto K, Takimura T, Sekine R, Kelly VP, Kamata K, Nishimura S, Yokoyama S. Structural basis of nonnatural amino acid recognition by an engineered aminoacyl-tRNA synthetase for genetic code expansion. Proc Natl Acad Sci USA. 2005; 102(5): 1366-71.

13. Yaremchuk A, Kriklivyi I, Tukalo M, Cusack S. Class I tyrosyltRNA synthetase has a class II mode of cognate tRNA recognition. EMBO J. 2002; 21(14):3829-40.

14. Qiu X, Janson CA, Smith WW, Green SM, McDevitt P, Johanson $K$, Carter P, Hibbs M, Lewis C, Chalker A, Fosberry A, Lalonde $J$, Berge J, Brown P, Houge-Frydrych CS, Jarvest RL. Crystal structure of Staphylococcus aureus tyrosyl-tRNA synthetase in complex with a class of potent and specific inhibitors. Protein Sci. 2001; 10(10):2008-16.

15. Brick P, Bhat TN, Blow DM. Structure of tyrosyl-tRNA synthetase refined at 2.3 A resolution. Interaction of the enzyme with the tyrosyl adenylate intermediate. J Mol Biol. 1989; 208(1):83-98.

16. Hartmann MD, Shkolnaya LA, Bourenkov GP, Strizhov NI, Bartunik HD. The structure of tyrosyl-tRNA synthetase from Mycobacterium tuberculosis. DOI:10.2210/pdb2jan/pdb.

17. Li T, Froeyen M, Herdewijn P. Comparative structural dynamics of Tyrosyl-tRNA synthetase complexed with different substrates explored by molecular dynamics. Eur Biophys J. 2008; 38(1):25-35.

18. Yesylevskyy SO, Savytskyi OV, Odynets KA, Kornelyuk AI. Interdomain compactization in human tyrosyl-tRNA synthetase studied by the hierarchical rotations technique. Biophys Chem. 2011; 154(2-3):90-8.

19. Savytskyi OV, Yesylevskyy SO, Kornelyuk AI. Asymmetric structure and domain binding interfaces of human tyrosyl-tRNA synthetase studied by molecular dynamics simulations. $J \mathrm{Mol} \mathrm{Re}$ cognit. 2013; 26(2):113-20.

20. Mykuliak VV, Kornelyuk AI. Conformational mobility of tyrosyltRNA synthetase from $M$. tuberculosis eubacteria according to computer modeling of molecular dynamics data. Physics of the Alive. 2011; 19(2):4-8.

21. Budiman ME, Knaggs MH, Fetrow JS, Alexander RW. Using molecular dynamics to map interaction networks in an aminoacyl-tRNA synthetase. Proteins. 2007; 68(3):670-89.

22. Thompson D, Plateau P, Simonson T. Free-energy simulations and experiments reveal long-range electrostatic interactions and substrate-assisted specificity in an aminoacyl-tRNA synthetase. Chembiochem. 2006; 7(2):337-44.

23. Thompson D, Simonson T. Molecular dynamics simulations show that bound $\mathrm{Mg}^{2+}$ contributes to amino acid and aminoacyl adenylate binding specificity in aspartyl-tRNA synthetase through long range electrostatic interactions. $J$ Biol Chem. 2006; 281(33): 23792-803.
24. Hughes SJ, Tanner JA, Miller AD, Gould IR. Molecular dynamics simulations of LysRS: an asymmetric state. Proteins. 2006; 62 (3):649-62.

25. Kapustina M, Carter CW Jr. Computational studies of tryptophanyl-tRNA synthetase: activation of ATP by induced-fit. $J \mathrm{Mol}$ Biol. 2006; 362(5):1159-80.

26. Pydiura NA, Kornelyuk AI. Flexible 3D structure of Bos taurus tyrosyl-tRNA synthetase suggests the existence of hinge mechanism provided by conservative Gly353 at interdomain linker. Biopolym Cell. 2012; 28(5):397-403.

27. Kornelyuk AI, Klimenko IV, Odynets KA. Conformational change of mammalian tyrosyl-tRNA synthetase induced by tyrosyl adenylate formation. Biochem Mol Biol Int. 1995; 35(2):317-22.

28. Mykuliak VV, Kornelyuk AI. Dynamic formation of the $\beta$-strand structure in the active site of tyrosyl-tRNA synthetase from $\mathrm{Mu}$ cobacterium tuberculosis eubakteria according to the molecular dynamics. Reports of the National Academy of Sciences of Ukraine. 2012; (5):158-162.

29. Hess B, Kutzner C, van der Spoel D, Lindahl E. GROMACS 4: Algorithms for highly efficient, load-balanced, and scalable molecular simulation. JChem Theory Comput. 2008; 4(3):435-47.

30. Hornak V, Abel R, Okur A, Strockbine B, Roitberg A, Simmerling $C$. Comparison of multiple Amber force fields and development of improved protein backbone parameters. Proteins. 2006; 65(3):712-25.

31. Bjelkmar P, Larsson P, Cuendet M, Hess B, Lindahl E. Implementation of the CHARMM force field in GROMACS: analysis of protein stability effects from correction maps, virtual interaction sites, and water models. $J$ Chem Theory Comput. 2010; 6 (2):459-66.

32. Wang J, Wang W, Kollman PA, Case DA. Automatic atom type and bond type perception in molecular mechanical calculations. J Mol Graph Model. 2006; 25(2):247-60.

33. Zoete V, Cuendet MA, Grosdidier A, Michielin O. SwissParam: a fast force field generation tool for small organic molecules. $J$ Comput Chem. 2011; 32(11):2359-68.

34. Salnikov A, Sliusar I, Sudakov O, Savytskyi O, KornelyukA. Virtual laboratory MolDynGrid as a part of scientific infrastructure for biomolecular simulations. Int J Computing. 2010; 9(4): 295-301.

35. Savytskyi OV, Sliusar IA, Yesylevskyy SO, Stirenko SG, Kornelyuk $A I$. Integrated tools for molecular dynamics simulation data analysis in the MolDynGrid virtual laboratory. Intelligent Data Acquisition and Advanced Computing Systems (IDAACS), 2011 IEEE $6^{\text {th }}$ International Conference on. 2011; 1:208-211.

36. Salnikov AO, Sliusar IA, Sudakov OO, Savytskyi OV, Kornelyuk $A I$. MolDynGrid virtual laboratory as a part of Ukrainian Academic Grid infrastructure. Intelligent Data Acquisition and Advanced Computing Systems: Technology and Applications, IDAACS 2009. IEEE International Workshop on. 2009:237-240.

37. The PyMOL Molecular Graphics System, Version 1.5. Schrodinger, LLC.

38. Laskowski RA, Swindells MB. LigPlot+: multiple ligand-protein interaction diagrams for drug discovery. $J$ Chem Inf Model. 2011; 51(10):2778-86.

39. Austin J, First EA. Comparison of the catalytic roles played by the KMSKS motif in the human and Bacillus stearothermophilus trosyl-tRNA synthetases. J Biol Chem. 2002; 277(32): 28394-9. 